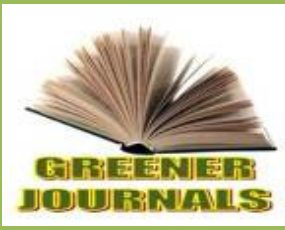

\title{
Assessment of Soil Properties under Shifting Cultivation System of Farming in Afikpo North Local Government Area of Ebonyi State, Nigeria
}

\section{Abua MA*, Iremoko CO and Igelle El}

Department of Geography and Environmental Science, University of Calabar, Calabar, Nigeria.

\section{ARTICLE INFO}

Article No.: 101716169

DOI: 10.15580/GJAS.2016.10.101716169

Submitted: 17/10/2016

Accepted: 22/10/2016

Published: 10/11/2016

${ }^{\star}$ Corresponding Author

Abua MA

E-mail: abuamoss4 real @gmail .$c 0 m$

Keywords:

Soil properties, Fallow, Forest, Cropping, Plots, Topsoil, Subsoil
An assessment of soil properties under shifting cultivation system of farming in Afikpo North Local Government Area of Ebonyi State, Nigeria was carried out. The soil varied from sand, silt and clay in texture. The bulk density of the topsoil and subsoil was 0.95 and $1.231 \mathrm{~g} / \mathrm{cm}^{3}, 0.1 .78$ and $1.2821 \mathrm{~g} / \mathrm{cm}^{3}, 1.2431$ and $1.388 \mathrm{~g} / \mathrm{cm}^{3}$, respectively for the forest, fallow and cropping plots. The soil $\mathrm{PH}$ in the topsoil and subsoil was slightly acidicand tending towards neutrality (PH 6.0-6.88)forthe forest, fallow and cropping plots.Organic Carbon contentin the topsoil and subsoil ranged from 1.15-4.87\%, Total Nitrogen content $0.074-0.246 \%$, Available Phosphorus 4.45-11.21 me/100g and Cation Exchange Capacity 3.95-10.69me/100g for the forest, fallow and cropping plots. Exchangeable Calcium, Sodium, Potassium and Magnesium ranged from $0.14-7.150 \mathrm{me} / 100 \mathrm{~g}$ in the forest, fallow and cropping plots respectively. The soil properties are low in the fallow and cropping plots. Although, these soil properties are higher in the fallow plot than cropping plot. There is low inherent fertility in the cropping plot and would require improvement to support agricultural use. The study therefore recommends Organic matter input, mulching and crop residue management, as key to replenishing nutrient in the fallow and cropping plots. 


\section{INTRODUCTION}

Shifting cultivation system of farming refers to a crop production system in which a variable but often short cultivation phase on land cleared by slash and burn alternates with a variable but sometimes long fallow period (Okigbo, 1982). The period of fallow serves among other things to regenerate soil nutrients through the reversion of land to bush. Although, the Clearing and burning process of shifting cultivation on sandy soil reported severe surface rusting and soil erosion in Nigeria (Lal, 1987; 2013). Nye and Greenland (1960), Aniekwe (2006), Enwezor et al., (1981) suggested that, shifting cultivation should be seen and studied on an ecological basis.

One of the potent ways by which man affects the ecosystem is cultivation on soil. Soil is encompassed of materials such as soil organic matter, minerals, air and water (Stewart et al., 2000). The alteration of the soil throughclearing and burning increase mean air, soil temperature and reduce infiltration (Lal, 2013; Ahn 1974). Similarly, the insufficient penetration of water in the soil as a result of reduce infiltration may lead to increase water runoff and soil nutrient reduction.

Several studies have been carried out on shifting cultivation and soil properties (Lal, 1987; Akamigbo \& Asadu, 1983; Gupta \& Germida, 1988; Aweto, \& Obe, 1993; Oguike \& Mbagwu; Abua \& Edet,
2007). Unfortunately, little work has been done about soil properties under shifting cultivation system of farming in Afikpo North Local Government Area of Ebonyi State, Nigeria. It is against this limitation that forms the trust of this study. The aim of the study is to examine soil physical and chemical properties on shifting cultivation system of farming in Afikpo North Local Government Area of Ebonyi State, Nigeria.

\section{MATERIALS AND METHODS}

\section{Study Location}

The study area is located in Afikpo North Local Government Area of Ebonyi State, Nigeria. The study lies approximately between Longitudes $7^{\circ} 55^{\prime} \mathrm{E}$ and Latitude $5^{0} 55^{\prime} \mathrm{N}$. The climate is basically humid tropical, with rainy and dry season. The annual rainfall ranged from $152 \mathrm{~cm}-203 \mathrm{~cm}$ which spans from April-October. The mean temperature ranged between $28^{\circ} \mathrm{C}-35^{\circ} \mathrm{C}$, evaporation and relative humidity is between $80 \%-90 \%$ respectively. Afikpo lies at an elevation of about $170 \mathrm{~m}$ above sea level. Erosion is more pronounce in the North and South along the anticlinoria, most generally occurring on planes by shale and silt stones. The tills and ridges composed of sand stone lithology. 


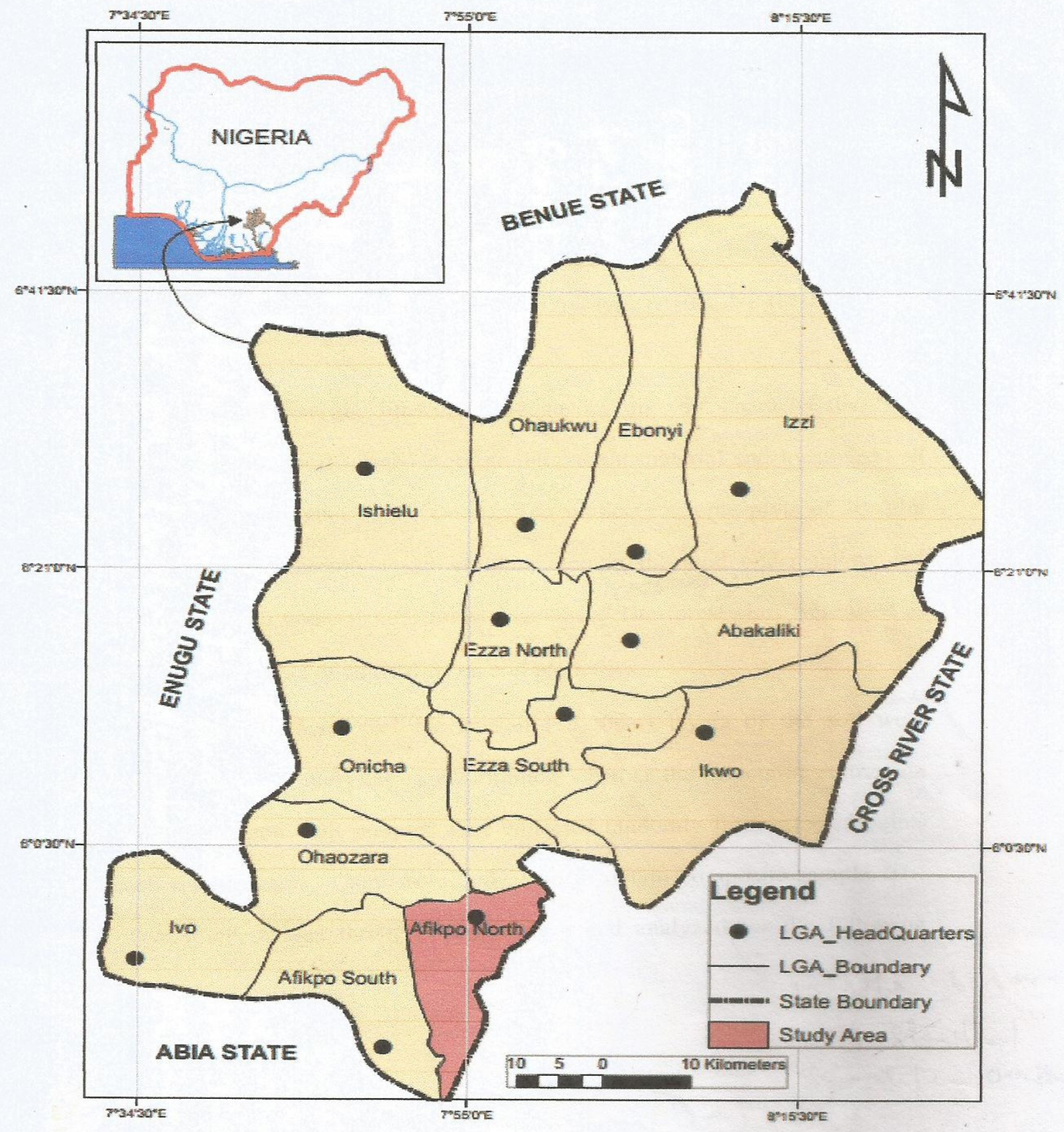

Figure 1: Showing map ofEbonyi State andAfikpo North Local Government Area 


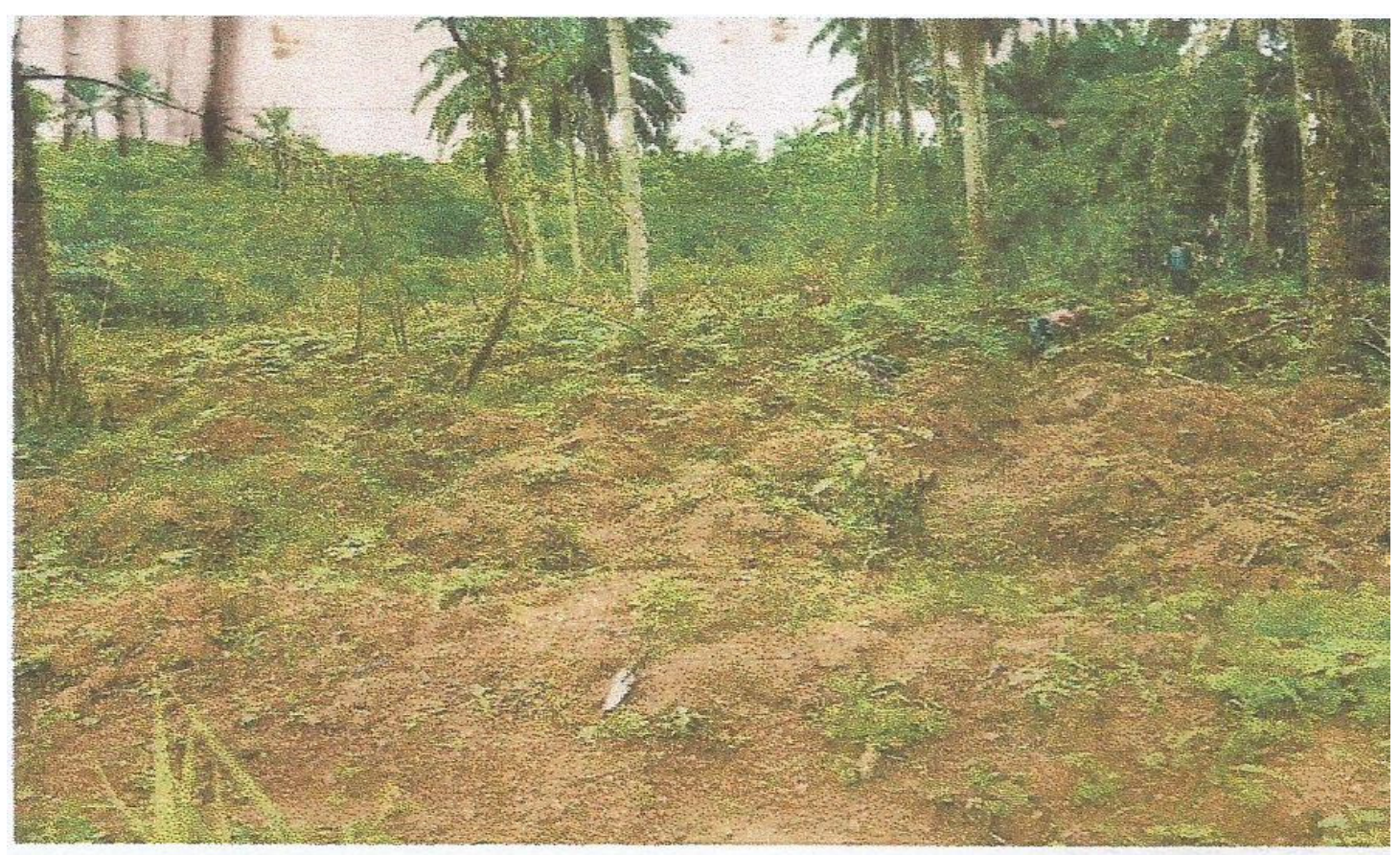

Figure 2: Cropping plot

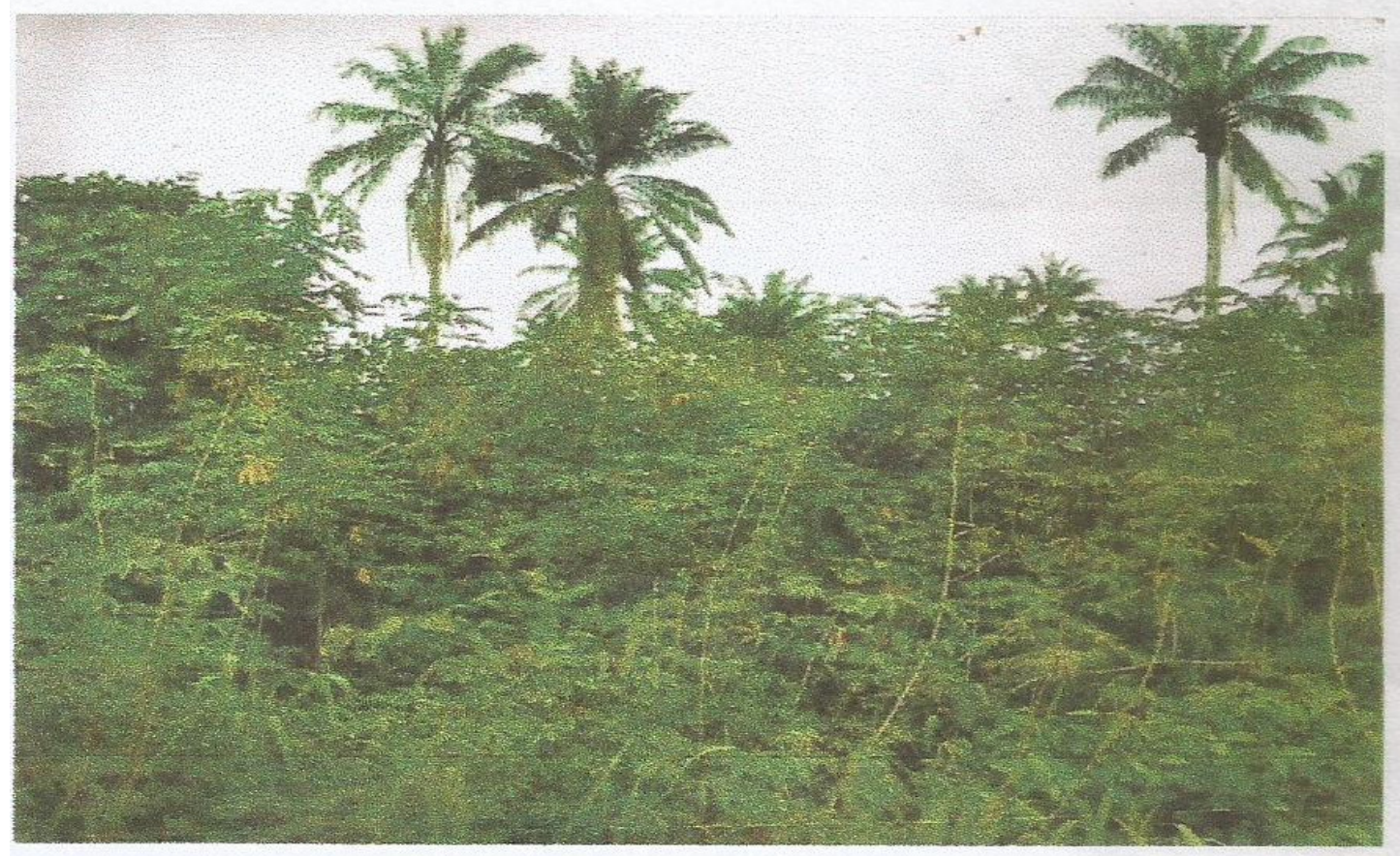

Figure 3: Cropping plot 


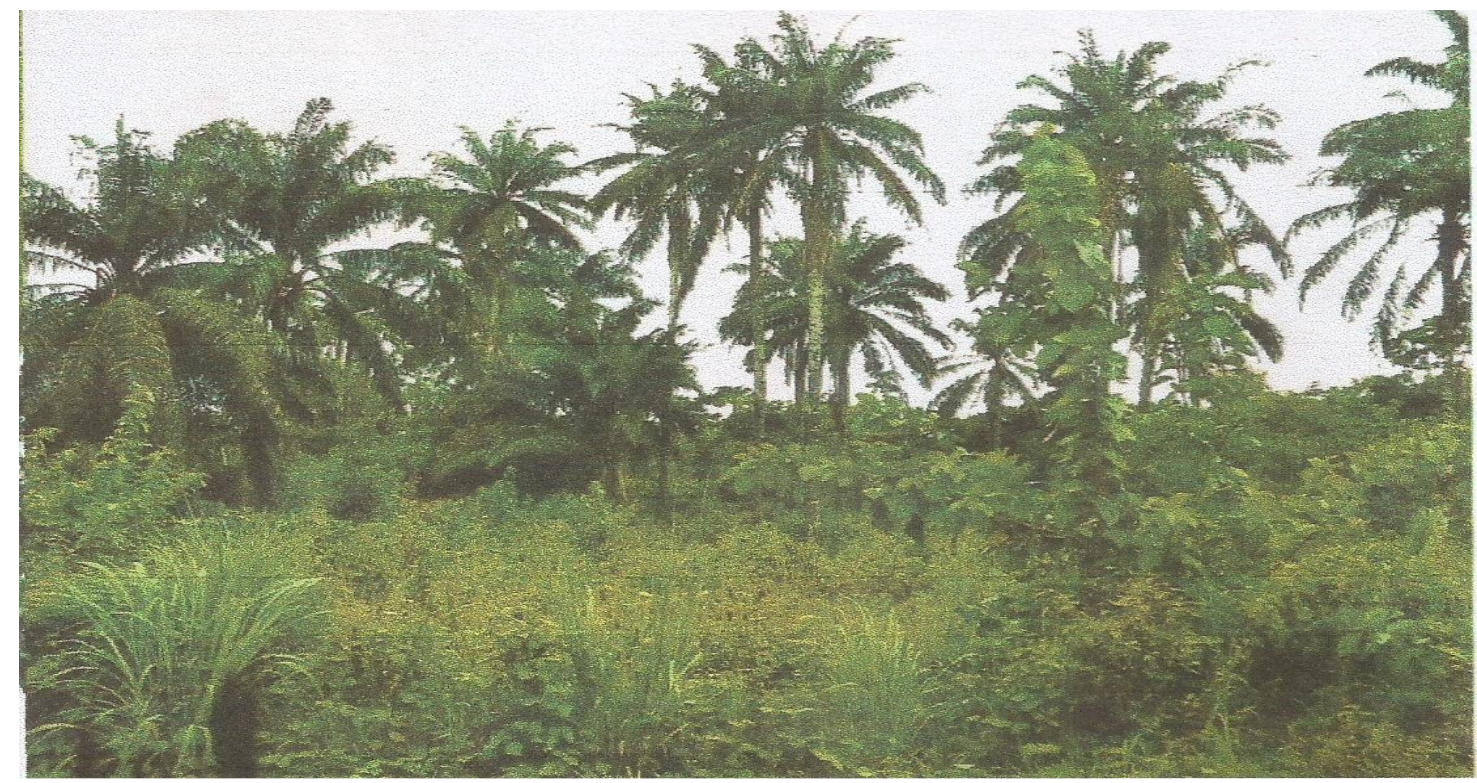

Figure 4: Fallow plot

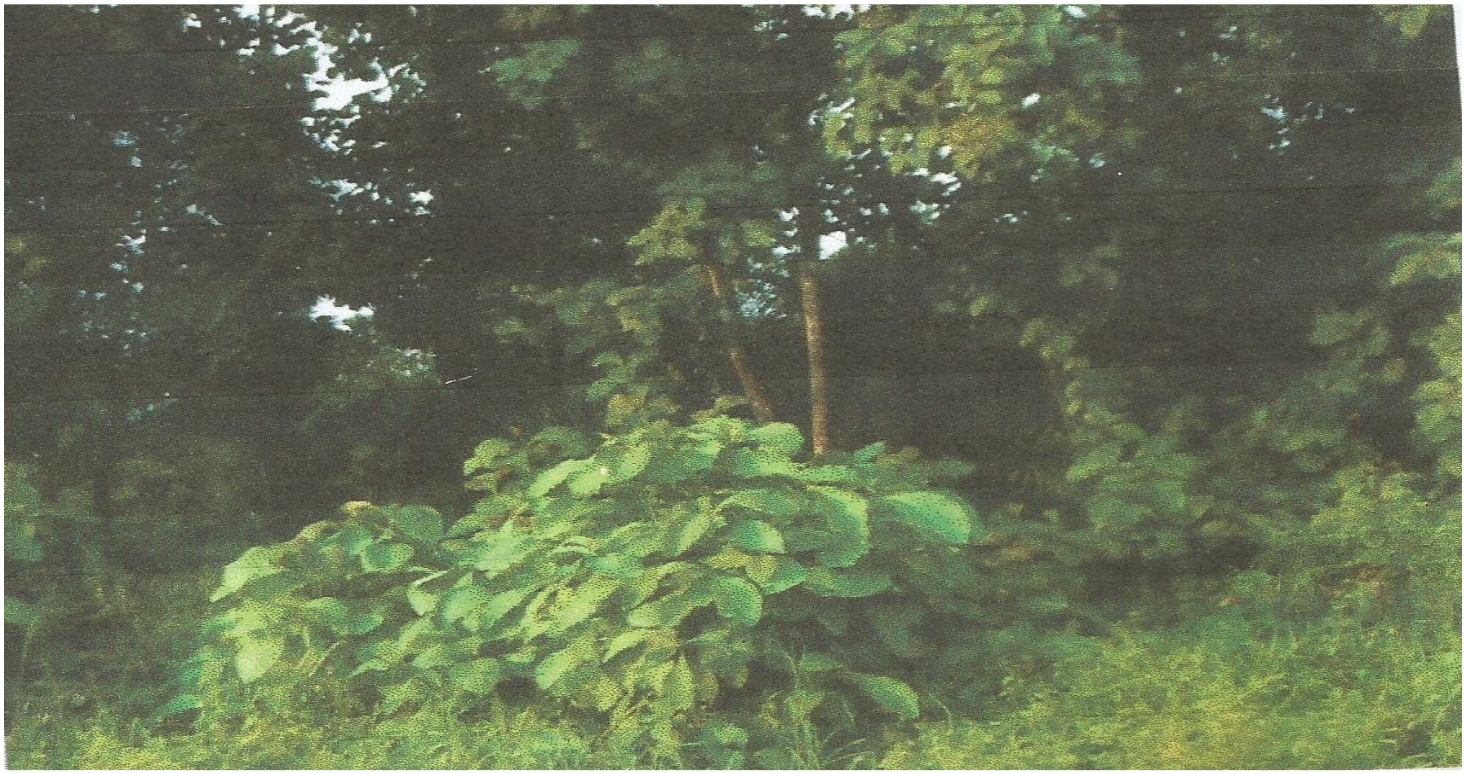

Figure 5: Forest plot

\section{Field Study}

The forest, fallow and cropping plots were dug in the topsoil $0-15 \mathrm{~cm}$ and subsoil $15-30 \mathrm{~cm}$. Ten replicate samples of $20 \mathrm{~m} \times 20 \mathrm{~m}$ were collected from topsoil and

\section{Laboratory Procedures}

Particle size composition was analyzed using hydrometer (Bouyocous, 1926). The bulk density sampler was used to collect samples and the result was expressed in mass per volume. Water holding capacity was determine by Sintered glass crucible. Soil PH was determined by potentiometer tribally in distilled water using soil to water ratio 1:1. Total Nitrogen was subsoil under forest, fallow and cropping plots. The samples were collected randomly from selected points within each sampled area. The soil samples were air dried, sieved through a $2 \mathrm{~mm}$ sieve and taken to Laboratory for analysis.

determined by regular Macro Kjeldahl Digestion method, Organic Carbon andAvailable Phosphorus by (Bray \& Kurtz, 1945). Exchangeable Sodium and Potassium were determined using flame Photometer. Exchangeable Magnesium and Calcium were determined using Atomic Absorption Spectrometer.

\section{Statistical Analysis}


The SPSS paired sample t-test (SPSS version 22) was used to determine the difference in soil properties betweenthe plots under studied.

\section{RESULTS AND DISCUSSION}

\section{Physical Properties}

Table 1 and 2 (Appendix 1)is the representation of the results of soil particle size, water holding capacity and bulk density. The tables represent the results of topsoil and subsoil of the forest, fallow and cropping plots. The total size distribution of sand in the topsoil varies from 69.7, 79.6 and $91.5 \%$ respectively for the forest, fallow and cropping plots. Silt constitutes 13.12, 7.88 and 3.76 $\%$, while clay constitutes $17.2,12.26$ and $4.51 \%$ respectively for the forest, fallow and cropping plots. Silt and clay content in the forest, fallow and cropping plots is less than $14 \%$ and less than $5 \%$ in the cropping plot. The dominant soil particle in the topsoil of the forest, fallow and cropping plots is sand.

The total size distributions of sand in the subsoil are $65.60,79.12$ and $88.80 \%$ respectively for the forest, fallow and cropping plots. Silt constitutes 12.0, 7.10 and $4.92 \%$, while clay constitutes $21.70,13.80$ and $6.18 \%$ respectively for the forest, fallow and cropping plots. The dominant soilparticle in the subsoil of the forest fallow and cropping plots is sand.Water holding capacity in the topsoil varies from $0.95,1.078$ and $1.2431 \%$, while subsoil constitutes 74.26, 73.26 and $72.80 \%$ respectively for the forest, fallow and cropping plots. The bulk density of the topsoil varies from $0.95,1.07$ and $1.24 \mathrm{~g} / \mathrm{cm}^{3}$, while subsoil ranged from $1.231,1.28$ and $1.38 \mathrm{~g} / \mathrm{cm}^{3}$ respectively in the forest fallow and cropping plots. Although, water holding capacity and bulk density increased with soil depth in the forest, fallow and cropping plots.

\section{Chemical Properties}

Table 3(Appendix 3) is the representation of the results of soil PH, Total Nitrogen, Organic Carbon, Available Phosphorus, Cation Exchange Capacity, Exchangeable Calcium, Sodium, Potassium and Magnesium. The tables represent the results of topsoil and subsoil of the forest, fallow and cropping plots. The soil $\mathrm{PH}$ in the topsoil and subsoil ranged fromPH 6.0-6.88. This indicates that, the soils are slightly acidic and tending towards neutrality. The soil $\mathrm{PH}$ is within optimal range for most crops. Soil PH for majority of agricultural crops ranged from 6.0-7.5(Brady, 1990). Total Nitrogen content in the topsoil and subsoil varies from $0.246-0.23 \%$, $0.114-0.79 \%$, and $0.074-0.083 \%$ respectively for the forest, fallow and cropping plots. The low rate of Nitrogen in the fallow and cropping plots may be attributed to leaching andlow Organic matter. Nitrogen is closely associated with soil Organic matter (Kowal \& Kassam, 1978; Holland et al., 1989; Ogban et al., 2001).
Organic Carbon content in the topsoil and subsoil varies from $4.8-430 \%, 0.459-1.804 \%$, and $1.19-1.15 \%$ respectively for the forest, fallow and cropping plots. The Organic Carbon in the fallow and cropping plots are low. This can be attributed to insolation and consequently greater flush of mineralization when the soil is rewetted (Enwezor et al., 1981; Abua \& Essoka, 2014). Available Phosphorus in the topsoil and subsoil varies from 11.21$8.90 \mathrm{me} / 100 \mathrm{~g}, 5.98-8.30 \mathrm{me} / 100 \mathrm{~g}$, and $4.45-5.3 \mathrm{me} / 100 \mathrm{~g}$ respectively for the forest, fallow and cropping plots. The value of Phosphorus for most productive soils is rated low (Holland etal., 1989).Available Phosphorus in the cropping plot was low.

Cation Exchange Capacity in the topsoil and subsoil varies from $10.69-9.93 \mathrm{me} / 100 \mathrm{~g}$, 7.43$5.34 \mathrm{me} / 100 \mathrm{~g}$, and $6.45-3.95 \mathrm{me} / 100 \mathrm{~g}$ respectively for the forest, fallow and cropping plots. The Cation Exchange Capacity of forest soil was higher than the fallow and cropping plots. This indicates that, Cation Exchange Capacity of forest soil is generally higher than in savannah soil, and attributed to the dominance of sand fraction (Kowal \& Kassan, 1978). Exchangeable potassium in the topsoil and subsoil varies from 0.36$0.32 \mathrm{me} / 100 \mathrm{~g}, 0.22-0.16 \mathrm{me} / 100 \mathrm{~g}$, and $0.19-0.24 \mathrm{me} / 100 \mathrm{~g}$ respectively for the forest, fallow and cropping plots. Potassium content in the follow and cropping plots are low. Farming has reported heavy demand on potassium especially those producing sugar or starch crops (Akpan-idiok \& Esu, 2001). Calcium in the topsoil and subsoil varies from $7.47-7.15 \mathrm{me} / 100 \mathrm{~g}$, 5.31$4.398 \mathrm{me} / 100 \mathrm{~g}$, and $4.48-2.336 \mathrm{me} / 100 \mathrm{~g}$ respectively for the forest, fallow and cropping plots. Calcium in the fallow plots was slightly low. This suggests that, the process of regeneration occurring in the fallow plot is allowing more effective nutrient cycling, hence, greater amount of Calcium in the topsoil (Aiboni, 1998). Calcium in the cropping plot was low and may be attributed to low nutrient cycling in the soil. Magnesium in the topsoil and subsoil varies from $2.136-1.89 \mathrm{me} / 100 \mathrm{~g}$, 1.388 $1.14 \mathrm{me} / 100 \mathrm{~g}$, and $1.110-0.83 \mathrm{me} / 100 \mathrm{~g}$ respectively for the forest, fallow and cropping plots. Exchangeable bases decreased with soil depth and are rated low to moderate (Haby et al., 1990; Obigbesan, 2009; Enwezor et al., 1989). Similarly, Exchangeable bases decreased with soil depth, and are moderate in the topsoil and low in the subsoil of the forest, fallow and cropping plots.

\section{Forest and Fallow Plots}

The paired sample t-test shows difference between forest and fallow plots with significant difference in the following soil propertiesOrganic Carbon 19.77, Soil PH 2.57, Total Nitrogen 12.03, Available Phosphorus 6.98, Cation Exchange Capacity 34.05, Exchangeable Calcium 18.69, Potassium 6.76, Sodium 8.72, Magnesium 12.60, Silt 5.32,Clay 5.70 and Sand 4.57 respectively for the topsoil. The difference between forest and fallow plots indicate significant difference in 
the following soil properties, Organic Carbon 19.71, Total Nitrogen 14.03, Exchangeable Calcium 7.51, Magnesium 9.95, Potassium 5.76, Sand 7.56, Clay 4.54, and Silt 10.75 respectively for the subsoil. Soil properties in the forest plot are higher than those in the fallow plot. This may suggest that, there is more stable and effective cycling of nutrient in the forest plot than fallow plot.

\section{Forest and Cropping Plots}

The paired sample t-test shows difference between forest and cropping plots with significant difference in the following soil properties Organic Carbon 43.16, Soil PH 6.77, Total Nitrogen 16.80, Available Phosphorus 15.30, Cation Exchange Capacity 33.61, Exchangeable Calcium 18.96, Potassium 5.36, Sodium 10.18, Magnesium 12.54 Sand 20.29 and Silt 13.88respectively for the topsoil. The difference between forest and cropping plots indicate significant difference in the following soil properties, Organic Carbon 22.20, Soil PH 8.47, Total Nitrogen 14.61, Cation Exchange Capacity 23.53, Exchangeable Potassium 4.09, Magnesium 10.35, Calcium 15.92, Sand 30.78, and Clay 20.63 respectively for the subsoil.Soil properties in the forest plot are higher than soil properties in the cropping plot. This suggests that, land use changes, especially cultivation of natural land in tropical areas have led to negative effect on soil organic matter components (Fallahazade \& Hajabbasi, 2011). This further revealed that, there are more stable and effective soil properties in the forested plot than cropping plot.

\section{Fallow and Cropping Plots}

The paired sample t-test shows difference between fallow and cropping plots with significant difference in the following soil properties Organic Carbon 14.80, Soil PH 3.60, Total Nitrogen 13.00, Available Phosphorus 3.13, Cation Exchange Capacity 23.37, Exchangeable
Calcium 19.67, Magnesium 12.29, Sodium 8.91, Sand 5.41, Silt 4.49, Clay 3.20, respectively for the topsoil. The difference between fallow and cropping plots indicate significant difference in the following soil properties, Organic Carbon 6.89, Soil PH 6.80, Available Phosphorus 3.11, Exchangeable Calcium 14.30, Potassium 3.77, , Magnesium 8.83,Silt 4.84, Sand 4.87 and Clay 4.73 respectively for the subsoil. Soil properties in the fallow plot are higher than soil properties in the cropping plot. This suggests that, Fallowing replenishes nutrient remove by crops, reduce erosion and leaching, and maintains better condition (Adejuwon\&Adesina, 1990; Juoetal., 1995). Although, tilling decreased Organic Carbon and Nitrogen in the soil (Cambelletal., 1998). The low rate of soil properties in the cropping plot may be attributed to cultivation of soil for agricultural use.

\section{CONCLUSION}

The results revealed that, the topsoil and subsoil of the forest, fallow and cropping plots varies from sand, silt and clay soil in texture. Sandy soil was dominant in the forest, fallow and cropping plots. The bulk densities of the soil were generally low and the soil PH was slightly acidic and tending towards neutrality. Nitrogen, Organic Carbon, Available Phosphorus, Exchangeable Calcium, Phosphorus, Magnesium and Sodium were low in the follow and cropping plots. Although, these soil properties are higher in the fallow plot than cropping plot. This revealed that, cultivation reduce soil nutrient status. This also implies that, there is low inherent fertility in the cropping plots and would require amendment to support agricultural use. The study therefore recommends Organic matter input and crop residue management, as key to replenishing nutrient in the fallow and cropping plots.

Table 1: Topsoil and subsoil physical properties of the forest, fallow and cropping plots

\begin{tabular}{|l|l|l|l|l|l|l|l|l|l|l|l|l|l|}
\hline \multicolumn{19}{|c|}{ SILT \% } & \multicolumn{3}{c|}{ Topsoil } \\
\hline \multicolumn{9}{|c|}{ SAND \% } & \multicolumn{3}{|c|}{ WATER HOLDING C. \% } \\
\hline $\begin{array}{l}\text { Sample } \\
\text { plots }\end{array}$ & forest & fallow & C.P & forest & fallow & C.P & forest & fallow & C.P & forest & fallow & C.P \\
\hline 1 & 67.8 & 79.8 & 89.8 & 15.0 & 7.0 & 5.0 & 17.2 & 13.2 & 5.2 & 70.4 & 69.5 & 72.6 \\
\hline 2 & 69.8 & 73.8 & 94.8 & 13.0 & 11.0 & 2.0 & 17.2 & 15.2 & 3.2 & 70.8 & 70.6 & 68.4 \\
\hline 3 & 71.8 & 87.8 & 89.8 & 10.0 & 5.0 & 5.0 & 18.2 & 7.2 & 5.2 & 69.5 & 75.6 & 72.8 \\
\hline 4 & 69.6 & 78.8 & 92.6 & 13.0 & 10.0 & 4.4 & 17.4 & 11.2 & 3.0 & 68.8 & 71.6 & 70.8 \\
\hline 5 & 67.4 & 86.8 & 87.2 & 15 & 6.0 & 6.0 & 17.6 & 7.2 & 6.8 & 72.6 & 70.4 & 74.2 \\
\hline 6 & 68.8 & 79.6 & 94.6 & 12.1 & 9.0 & 2.3 & 18.2 & 11.4 & 3.1 & 70.6 & 69.5 & 70.6 \\
\hline 7 & 69.6 & 73.8 & 88.6 & 12.0 & 10.0 & 5.2 & 18.4 & 16.2 & 6.2 & 68.6 & 69.8 & 68.4 \\
\hline 8 & 67.8 & 87.6 & 94.6 & 14.0 & 5.0 & 2.3 & 18.2 & 3.1 & 3.1 & 72.4 & 70.4 & 70.8 \\
\hline 9 & 72.6 & 73.8 & 89.4 & 13.0 & 11.0 & 4.9 & 14.4 & 5.7 & 5.7 & 70.2 & 72.4 & 66.8 \\
\hline 10 & 71.8 & 74.6 & 94.4 & 13.0 & 7.0 & 2.0 & 15.2 & 3.6 & 3.6 & 70.6 & 70.6 & 74.0 \\
\hline $\mathrm{X}$ & 69.7 & 79.6 & 91.5 & 13.12 & 7.88 & 3.76 & 17.2 & 4.51 & 4.51 & 70.45 & 70.5 & 2.37 \\
\hline SD & 1.822 & 6.245 & 3.206 & 1.528 & 2.421 & 1.591 & 1.35 & 1.463 & 1.463 & 1.32 & 1.84 & 2.37 \\
\hline
\end{tabular}




\begin{tabular}{|c|c|c|c|c|c|c|c|c|c|c|c|c|}
\hline \multicolumn{13}{|l|}{ Subsoil } \\
\hline \multicolumn{4}{|c|}{ SAND \% } & \multicolumn{3}{|c|}{ SILT \% } & \multicolumn{3}{|c|}{ CLAY \% } & \multicolumn{3}{|c|}{ WATER HOLDING C. \% } \\
\hline $\begin{array}{l}\text { Sample } \\
\text { plots }\end{array}$ & forest & fallow & C.P & forest & fallow & C.P & forest & fallow & C.P & forest & fallow & C.P \\
\hline 1 & 63.8 & 81.8 & 88.2 & 13.0 & 7.0 & 5.0 & 23.2 & 11.2 & 7.2 & 76.4 & 72.4 & 75.6 \\
\hline 2 & 65.8 & 71.8 & 89.8 & 13.0 & 9.0 & 5.0 & 21.2 & 19.2 & 5.2 & 75.0 & 69.4 & 73.0 \\
\hline 3 & 67.8 & 85.8 & 88.8 & 13.0 & 5.0 & 5.0 & 19.2 & 9.2 & 6.2 & 71.8 & 77.8 & 73.4 \\
\hline 4 & 64.5 & 75.6 & 89.6 & 12.0 & 7.0 & 5.0 & 23.5 & 17.4 & 5.4 & 74.0 & 74.0 & 74.6 \\
\hline 5 & 67.8 & 84.2 & 88.9 & 13.0 & 7.0 & 4.6 & 19.2 & 8.8 & 6.5 & 76.2 & 76.2 & 72.8 \\
\hline 6 & 63.5 & 70.6 & 89.6 & 12.0 & 8.0 & 4.8 & 24.5 & 21.4 & 5.6 & 70.4 & 70.4 & 74.0 \\
\hline 7 & 65.6 & 81.6 & 88.2 & 13.0 & 6.0 & 5.0 & 21.4 & 21.2 & 6.8 & 76.0 & 76.0 & 73.6 \\
\hline 8 & 65.8 & 72.0 & 88.5 & 13.0 & 9.0 & 5.2 & 21.2 & 19 & 6.3 & 76.2 & 76.2 & 75.2 \\
\hline 9 & 63.6 & 85.8 & 90.2 & 13.0 & 5.0 & 4.8 & 23.4 & 9.5 & 5.0 & 72.0 & 72.0 & 72.8 \\
\hline 10 & 67.8 & 82.0 & 87.0 & 12.0 & 8.0 & 4.8 & 20.2 & 10.0 & 7.6 & 74.6 & 74.6 & 74.6 \\
\hline$X$ & 65.60 & 79.12 & 88.80 & 12.74 & 7.10 & 4.92 & 21.70 & 13.80 & 6.18 & 74.26 & 73.26 & 72.80 \\
\hline SD & 1.747 & 6.00 & 0.957 & 0.483 & 1.449 & 0.169 & 1.873 & 4.885 & 0.873 & 12.158 & 2.687 & 1.006 \\
\hline
\end{tabular}

C. $\mathrm{P}=$ Cropping plot

Table 2: Bulk density of topsoil and subsoil of the forest, fallow and cropping plots

\begin{tabular}{|l|l|l|l|l|l|l|}
\hline \multirow{2}{*}{ S/No } & \multicolumn{2}{l|}{ Forest plots } & \multicolumn{2}{l|}{ Follow plots } & \multicolumn{2}{l|}{ Cropping plots } \\
\cline { 2 - 7 } & $\begin{array}{l}\text { Topsoil } \\
0-15 \mathrm{~cm} \\
\left(\mathrm{~g} / \mathrm{cm}^{3}\right)\end{array}$ & $\begin{array}{l}\text { Subsoil } \\
15-30 \mathrm{~cm} \\
\left(\mathrm{~g} / \mathrm{cm}^{3}\right)\end{array}$ & $\begin{array}{l}\text { Topsoil } \\
0-15 \mathrm{~cm} \\
\left(\mathrm{~g} / \mathrm{cm}^{3}\right)\end{array}$ & $\begin{array}{l}\text { Subsoil } \\
15-30 \mathrm{~cm} \\
\left(\mathrm{~g} / \mathrm{cm}^{3}\right)\end{array}$ & $\begin{array}{l}\text { Topsoil } \\
0-15 \mathrm{~cm} \\
\left(\mathrm{~g} / \mathrm{cm}^{3}\right)\end{array}$ & $\begin{array}{l}\text { Subsoil } \\
15-30 \mathrm{~cm} \\
\left(\mathrm{~g} / \mathrm{cm}^{3}\right)\end{array}$ \\
\hline 1 & 0.845 & 1.230 & 1.001 & 1.221 & 1.240 & 1.490 \\
\hline 2 & 1.121 & 1.236 & 1.200 & 1.362 & 1.290 & 1.390 \\
\hline 3 & 1.0 & 1.263 & 1.101 & 1.201 & 1.330 & 1.470 \\
\hline 4 & 0.921 & 1.290 & 0.860 & 1.254 & 1.221 & 1.320 \\
\hline 5 & 0.826 & 1.220 & 1.240 & 1.254 & 1.201 & 1.171 \\
\hline 6 & 0.82 & 1.24 & 1.470 & 1.362 & 1.225 & 1.262 \\
\hline 7 & 1.0 & 1.37 & 1.024 & 1.330 & 1.140 & 1.650 \\
\hline 8 & 0.86 & 1.23 & 1.024 & 1.240 & 1.300 & 1.612 \\
\hline 9 & 0.133 & 1.221 & 1.201 & 1.372 & 1.254 & 1.320 \\
\hline 10 & 0.845 & 1.01 & 0.002 & 1.225 & 1.230 & 1.201 \\
\hline $\mathrm{X}$ & 0.95 & 1.231 & 1.078 & 1.2821 & 1.2431 & 1.388 \\
\hline SD & 0.155 & 0.0855 & 0.136 & 0.081 & 0.136 & 0.081 \\
\hline
\end{tabular}

Table 3: Topsoil and subsoil chemical properties ofthe forest, fallow, and cropping plots

Topsoil

\begin{tabular}{|c|c|c|c|c|c|c|c|c|c|c|c|c|}
\hline \multicolumn{4}{|c|}{ ORGANIC CARBON \% } & \multicolumn{3}{|c|}{$\begin{array}{l}\text { TOATAL NITROGEN } \\
\%\end{array}$} & \multicolumn{3}{|c|}{$\begin{array}{l}\text { AVAILABLE } \\
\text { PHOSPHORUSme } / 100 \mathrm{~g}\end{array}$} & \multicolumn{3}{|c|}{$\begin{array}{ll}\text { CATION } & \text { EXCHANGE } \\
\text { CAPACITY }(\mathrm{me} / 100 \mathrm{~g})\end{array}$} \\
\hline $\begin{array}{l}\text { Sample } \\
\text { plots }\end{array}$ & forest & fallow & C.P & forest & fallow & C.P & Forest & fallow & C.P & forest & fallow & C.P \\
\hline 1 & 4.71 & 2.04 & 1.11 & 0.26 & 0.099 & 0.064 & 11.5 & 7.36 & 4.75 & 11.84 & 8.22 & 7.19 \\
\hline 2 & 5.25 & 2.41 & 1.26 & 0.28 & 0.141 & 0.091 & 13.2 & 6.43 & 5.15 & 11.61 & 8.06 & 6.94 \\
\hline 3 & 4.54 & 1.40 & 0.76 & 0.20 & 0.074 & 0.050 & 10.2 & 3.06 & 3.02 & 10.11 & 7.03 & 6.17 \\
\hline 4 & 5.10 & 1.65 & 0.90 & 0.28 & 0.091 & 0.060 & 9.8 & 4.25 & 2.02 & 10.33 & 7.26 & 6.21 \\
\hline 5 & 4.93 & 2.71 & 1.48 & 0.21 & 0.127 & 0.082 & 13.4 & 7.56 & 5.17 & 10.50 & 7.27 & 6.46 \\
\hline 6 & 4.84 & 1.94 & 1.10 & 0.26 & 0.097 & 0.063 & 12.6 & 6.43 & 4.95 & 11.30 & 7.79 & 6.68 \\
\hline 7 & 5.10 & 2.80 & 1.53 & 0.28 & 0.153 & 0.099 & 9.6 & 8.02 & 4.62 & 9.19 & 6.35 & 5.49 \\
\hline 8 & 4.66 & 2.32 & 1.26 & 0.19 & 0.101 & 0.066 & 8.7 & 7.67 & 4.35 & 11.68 & 8.13 & 6.96 \\
\hline 9 & 4.84 & 2.11 & 1.15 & 0.26 & 0.115 & 0.075 & 12.6 & 4.08 & 5.16 & 11.08 & 7.68 & 6.822 \\
\hline 10 & 4.76 & 2.62 & 1.43 & 0.24 & 0.143 & 0.093 & 10.5 & 4.95 & 5.26 & 9.32 & 6.51 & 5.60 \\
\hline$X$ & 4.87 & 2.20 & 1.19 & 0.246 & 0.114 & 0.074 & 11.21 & 5.98 & 4.45 & 10.69 & 7.43 & 6.45 \\
\hline SD & 0.223 & 0.459 & 0.248 & 0.034 & 0.026 & 0.016 & 1.670 & 1.764 & 1.080 & 0.960 & 0.661 & 0.57 \\
\hline $\mathrm{PH}$ & & SOIL & \multicolumn{3}{|c|}{$\begin{array}{l}\text { EXCHANGEABLE } \\
\text { CALCIUM (me/100g) }\end{array}$} & \multicolumn{3}{|c|}{$\begin{array}{l}\text { MANGNESIUM } \\
(\mathrm{me} / 100 \mathrm{~g})\end{array}$} & $(\mathrm{me} / 100 \mathrm{~s}$ & & \multicolumn{2}{|c|}{$\begin{array}{l}\text { POTASSIUM } \\
\text { (me/100g) }\end{array}$} \\
\hline
\end{tabular}


Annual Conference of Soil Science Society of Nigeria, 81-90.

Akanigbo, F. O. R. and Asadu, C. L. A. (1983). Influence on parent materials on the soil of Southeastern Nigeria. East Africa Agricultural Journal 48:81-91.

Akpan-Idiok, A. K. and Esu, I. E. (2001). Morphological characteristics of mangrove swamp soils in Cross River Estuary Southeast, Nigeria. Proceedings of the 27th Annual Conference of Soil Society of Nigeria, Calabar, 60-68.

Aniekwe M. A. N. (2006). Soil quality assessment and monitoring. Enugu: New Generational Ventures Ltd., 19-21, 178-181.

Aweto, A. O. and Obe O. A., (1993). Comparative effects of a tree crop cocoa and shifting cultivation on a forest soil in Nigeria. Department of Geography, University of Ibadan, Ibadan, Nigeria. Volume 13, number 3.

Bouyocous, G. J. (1926). Estimation of the colloidal materials in soil. Soil Science, 64:362

Brady, N. C. (1990). The nature and properties of soils $10^{\text {th }}$ edition, Macmillan Pub.Co.New York.

Bray, R. H. and Kurtz, L. T. (1945). Determination of total organic and available forms of phosphorus in Soil Sciences, 5: 39-45.

Campbell, C. A., McConkey, B. G., Biederbeck, V. O., Zenter, R. P. Curtin, D. and Peru, M. R. (1998). Long term effect of tillage and fallow frequency on soil quality attributes in the clay soil in semi-arid Southwestern Saskatchewan. Soil Tillage Resource, 46, $135-144$.

Enwezor, W. O., Ohiri, A. C., Opuwaribo, E. E., \&Udo, E. J. (1989). Review of fertility use in crops in Southeastern Nigeria. Fertilizer Procurement and Distribution, Lagos, Nigeria.P.420.

Enwezor, W. O., Udo, E. J., \&Sobulo, R. A. (1981).Fertility status and productivity of the "Acid Sand".In Acid sands of Northern Nigeria. Soil Science Society of Nigeria Spectrum Publication Monograph, 1: 56-73.

Fallahazade, J. and Hajabbasi, M. A. (2011). Soil organic matter status changes with cultivation of overgrazed pastures in semi-dry west central Iran. International Journal of Soil Science, 6(2): 114-123.

Gupta, V. V. and Germida, J. J. (1988).Distribution of microbial biomass and its activity in different soil aggregate size classes as affected by cultivation. Soil Bio.Biochem, 20:777-786.

Harby, V. A., Rusette, M. P. and Skogley, E. O. (1990).Testing soils for Potassium, Calcium and Magnesium. 181-227. In: Westmaster, R. L. (ed).
Soil testing and plant analysis. $3^{\text {rd }}$ ed. SSSA. Madison: Washington DC.

Holland, M. D., Allen, R. K. G., Barten, D. \& Murphy, S. T. (1989).Land evaluation and agricultural recommendations for Cross River National Park, Oban Division.Prepared by the Overseas Development Resource Institute in collaboration with WWF for the Federal Republic of Nigeria and the Cross River State Government.

Juo, A. S. R., Franzluebbers, K., Dabiri, A. \&lkhile, B. (1995). Changes in soil properties during long term fallow and continuous cultivation after forest clearing in Nigeria.Agricultural Ecosystem Environment, 56: 9-18.

Kowal, J. M. and Kassam A. H. (1978).Agricultural Ecology of Savanna.A study of West Africa. Clarendon press, Oxford, UK.

Lal, R. (1987). Tropical Ecology and Physical Edephology, Wiley, New York.

Lal, R. (2013). Soil Ecosystem Services in Lal et al (eds). Ecosystem Services and Carbon sequentration in the Bioshere, Sringer, London,Pp.11-28.

Nye, R. H. and Greenland, D. S. (1960).Soil under shifting cultivation. Technical communication No. 51 Harpenden.

Ogban, P. I., Akwue, I. P. and Maduako, O. (2001).Properties and management of catenary soils on coastal plain sands in Southern Nigeria, in proceedings of the $25^{\text {th }}$ Annual conference of Soil Science Society of Nigeria, 45-52.

Oguike, P. C. and Mbagwu, J. S. C. (2009). Variations in some physical properties and organic matter content of soils coastal plain sand under different land used types. World Journal of Agricultural Science, 5 (1): 63-69.

Okigbo, B. N. (1982). Shifting cultivation in tropical Africa.Definition and description. Page.18. In: The future of shifting cultivation in Africa and the task of Universities. Proceedings of the international workshop on shifting cultivation, teaching and research at University level Ibadan, Nigeria. Page (ed) Bunting, A. H. and Edward, B., FOAUN Rome.

Sanchez, P. (1995). Science in Agroforestry.Agroforestry System, 30:5-55.

Stewart, R., Nathan, B. and Oghenekome, O. (2000).Soil Science for Archeologist. Page (ed), Michael, R. and Virginia, H., Florida Agricultural and Mechanical University and Southeast Archeological Centre, National Park Service Volume 1. 